\title{
Pirational Choice: The Economics of Infamous Pirate Practices*
}

\author{
Peter T. Leeson ${ }^{\dagger}$
}

George Mason University

\begin{abstract}
This paper investigates the economics of infamous pirate practices. Two closely related economic theories - the theory of signaling and the theory of reputation building - explain these practices. First, I examine the pirate flag, "Jolly Roger," which pirates used to signal their identity as unconstrained outlaws, enabling them to take prizes without costly conflict. Second, I consider how pirates combined heinous torture, public displays of "madness," and published advertisement of their fiendishness to establish a reputation as "hair triggers" that prevented costly captive behaviors. Pirates' infamous practices reduced their criminal enterprise's costs and increased its revenues, enhancing the profitability of life "on the account."
\end{abstract}

*I am especially grateful to David Myatt, three anonymous referees, and seminar participants at the University of Chicago and New York University for their insightful and thorough comments on an earlier draft of this paper. I also thank Pete Boettke, Tyler Cowen, Chris Coyne, Edward Glaeser, Andrei Shleifer, Russ Sobel, Bill Trumbull, and Claudia Williamson for helpful remarks and suggestions, and the Mercatus Center at George Mason University for financial support. Doug Rogers provided excellent research assistance.

${ }^{\dagger}$ Email: pleeson@gmu.edu. Address: Department of Economics, George Mason University, MSN 3G4, Fairfax, VA 22030. 


\section{Introduction}

Few characters in history inspire as much fascination or mystery as pirates. Pirate symbols, from skull-emblazed flags, to eye patches and wooden legs, pervade modern popular culture. Despite this, or perhaps because of it, in many people's minds pirate fantasy and reality are indistinguishable. Buried treasure, colorful captains, and salty sea talk are permanently part of pirates' intriguing lore. Many infamous pirate practices are pure fiction. But a number of others not only have historical foundations; they have rational choice foundations as well.

This paper considers two such practices: pirates' infamous flag of skull and bones, the "Jolly Roger," and pirates' infamous "fondness" for torture. Two closely-connected economic theoriesthe theory of signaling and the theory of reputation building - explain these practices. Michael Spence (1973) pioneered the theory of signaling in the context of the job market. Signaling is a means of coping in a world of asymmetric information. Many employers, for instance, find it prohibitively costly to directly observe potential employees' quality ex ante. Information about potential employees' quality is therefore private. Since employers are willing to pay high-quality employees more than low-quality ones, both types of potential employees have an incentive to try and communicate, or signal, to employers that they're high quality by engaging in behaviors employers can cheaply and directly observe.

To distinguish themselves from low-quality potential employees, high-quality potential employees must send signals correlated with their quality. Verbally communicating high quality, for example, wouldn't work. Talk is cheap; it's equally inexpensive for both high- and low-quality potential employees to claim they're the former. The incentive for both types of potential employees to claim they're high quality results in a pooling equilibrium. This undermines high-quality potential employees' ability to distinguish themselves from low quality ones and with it their ability to command higher wages.

High-quality potential employees can prevent this outcome if they can find signals sufficiently cheap for them, but prohibitively costly for low-quality potential employees, to send. A signal with this cost structure satisfies the "single-crossing property." Graduating from MIT, for instance, is an example of such a signal.

Because they're smarter and harder working than their low-quality counterparts, it's relatively cheap for high-quality potential employees to graduate from MIT but prohibitively costly for low-

quality ones to do so. And, unlike intelligence or work ethic, employers can directly and cheaply 
observe potential employees' educational backgrounds. High-quality potential employees therefore have an incentive to earn degrees from MIT while low-quality potential employees do not. The result is a separating equilibrium wherein high- and low-quality potential employees engage in different behaviors allowing employers to determine their underlying types and compensate them accordingly.

Signaling theory has a variety of applications. ${ }^{1}$ One of the most innovative has been to organized criminals. Diego Gambetta (1994) spearheaded this research with his analysis of the Sicilian Mafia. The dark sunglasses, pinstriped suits, and other classic stylings we associate with Mafiosi, Gambetta argued, are easily observable attributes they use to communicate their Mafia membership to victims. Mafiosi have an incentive to signal their identity to distinguish themselves from common street hoods who might pose as Mafiosi to extort entrepreneurs.

The problem with many of these signals is that, like cheap talk, they're inexpensive for "fakers" to send. Wearing dark sunglasses and pinstripe suits is as cheap for true Mafiosi as it is for Mafioso poseurs. Because of this, poseurs also have an incentive to send these signals. The single-crossing property is violated and a pooling equilibrium emerges, undermining genuine Mafiosi's aims.

An important paper by Smith and Varese (2001) builds on Gambetta's analysis and identifies the emergence of a semi-separating equilibrium in a dynamic setting. In their model, Mafiosi's willingness to punish non-compliant entrepreneurs is initially an effective signal because genuine Mafiosi find it relatively inexpensive to punish non-payers but fakers find it too expensive to do so. This signal's success, however, encourages fakers to enter the "market" and begin extorting entrepreneurs as well. Mafiosi can try and prevent this outcome by punishing fakers. But ultimately their success is their undoing. If Mafiosi succeed in driving all fakers from the market, businessmen always believe genuine Mafiosi are extorting them and so pay. But if victims always pay, fakers again have an incentive to re-enter the market. The result is what Smith and Varese (2001) call "turbulence." In equilibrium, fakers sometimes demand payment and businessmen sometimes pay.

To solve the problems of credibly communicating their identity, some organized criminals have resorted to much costlier signals - signals so costly poseurs never want to send them, even when they're successful. For instance, members of the Yakuza, the Sicilian Mafia's Japanese counterpart, cover their bodies in tattoos and chop off their fingers to credibly communicate their identity. These signals' success doesn't attract fakers because, unlike genuine Yakuza, fakers' cost of tattooing their whole bodies or lopping off their fingers remains too high.

\footnotetext{
${ }^{1}$ See, for instance, Leeson (2008b); Posner (1998); Zahavi (1975).
} 
The theory of reputation building is closely connected to the theory of signaling and also illuminates how agents cope with informational asymmetries. Reinhard Selten's (1978) "chain store paradox" highlighted the apparent difficulty of explaining incumbent firms' decisions to behave aggressively toward new entrants into their markets when incumbents and potential competitors are rational. Stated simply, incumbents' threat to behave aggressively toward entrants isn't credible because sharing the market with a new competitor pays more than behaving aggressively toward the competitor once the competitor has entered.

The Gang of Four's (Milgrom and Roberts 1982; Kreps and Wilson 1982; see also, Kreps, Milgrom, Roberts, and Wilson 1982) seminal insight was that in a world in which there are multiple potential entrants (or what is equivalent, play is repeated), some of whom are uncertain about the incumbent's motives (or are uncertain about each other's certainty of the incumbent's motives), behaving aggressively, though unprofitable in the short run, can be profit-maximizing in the long run. The reason for this is that behaving aggressively with early entrants can create a reputation that deters future potential competitors from entering the market.

As with signaling theory, Gambetta (1993, 1994; see also, Reuter 1983) and Smith and Varese (2001) have also applied the theory of reputation building to organized criminals. As Gambetta (1994: 355) points out, "The importance of reputation in the mafia can scarcely be exaggerated." A major reason for this is the helpful effect the right reputation can have on reducing the Mafia's production costs, such as extracting payment from victims. Establishing such a reputation can involve up-front costs, however. Like incumbent firms that take losses today to create a reputation for aggressive behavior that deters future competitors, criminal "firms," such as the Mafia, may also find it profitable to punish non-payers today, even if this behavior creates lower current payoffs, since doing so ensures larger future profits by convincing future victims to pay.

Like Mafiosi or Yakuza, pirates were organized criminals. And like other organized criminals, pirates sought profit in the face of informational asymmetries. Pirates therefore confronted similar obstacles of credibly communicating their piratical identity and creating a reputation that could help them achieve their goal. ${ }^{2}$ It's not surprising, then, that the theories of signaling and reputation

\footnotetext{
${ }^{2}$ Becker (1968) was the first to apply the logic of rational-choice decision making to criminals. Following him, a number of others extended this logic to decision making in the context of organized outlaws. Fiorentini and Peltzman (1995) provide the most comprehensive collection of essays that consider the economics of criminal organization. In addition, a large literature discusses the economic impact of organized crime, activities of criminal organizations, optimal strategies for preventing organized crime, and reasons for its emergence and success in some territories but not others (besides Fiorentini and Peltzman 1995, see for instance, Anderson 1979; Arlacchi 1986; Chang, Lu, and Chen 2005; Dick 1995; Garoupa 2000; Jankowski 1991; Jennings 1984; Konrad and Skaperdas 1998; Reuter 1983, 1987; Skaperdas 2001; Varese 2001, 2006a).
} 
building play prominent roles in explaining and understanding pirates' infamous practices. In what follows I explore the application of these important theories to the case of sea bandits like Blackbeard, "Calico" Jack Rackam, and "Black Bart" Roberts.

My discussion contributes to a small but growing literature that uses economics to analyze the profit-maximizing strategies of organized criminals. ${ }^{3}$ It highlights signaling and reputation building in pirates' particular context and explores novel aspects of these theories' application that the unique features of pirates' criminal enterprise create. In particular my analysis illuminates the strategies criminals use to establish their identities and how they coordinate on these strategies; the communication mechanisms they use to broadcast and manipulate their public images, and thus propagate their reputations; and the kinds of informational asymmetries criminals' victims confront in dealing with predators and how these asymmetries work for or against criminals in their pursuit of profit.

\section{Buried Treasure: A Note on Sources}

To explore the economics of infamous pirate practices I consider late 17th- and early 18th-century (1660-1730) sea bandits who occupied the waterways that formed major trading routes surrounding the Bahamas, connecting Europe and the North American sea coast, between Cuba and Haiti, and around Madagascar. These areas encompass major portions of the Atlantic Ocean, Indian Ocean, Caribbean Sea, and Gulf of Mexico. The trade routes connecting the Caribbean, North America's Atlantic sea coast, and Madagascar formed a loop called the "Pirate Round" that many pirates traveled in search of prey.

My investigation draws on the most important primary source historical documents relating to pirates. The first of these is Captain Charles Johnson's General History of the Pyrates (17261728), which contains reports on a number of history's most famous pirates related by a pirate contemporary. ${ }^{4}$ I also draw on Alexander Exquemelin's (1678) invaluable account of the 17th-

\footnotetext{
${ }^{3}$ Besides those papers cited above, see also, Skarbek (2008). Leeson (2007, 2008a, 2009) explores other aspects of the economics of pirates' criminal organization in particular.

4 "Captain Johnson" is a pen name used by the author of A General History of the Pyrates. His true identity remains unknown. In 1932, John R. Moore claimed that Johnson was in fact Daniel Defoe. In the late 1980s, however, this view was overturned (see, Furbank and Owens 1988) and today many pirate historians do not believe that Defoe is the author of this important book (see, for instance, Cordingly 2006; Rediker 2004; Woodard 2007; for the opposing view see, Rogozinski 2000). Whatever Johnson's true identity, it's agreed that he "had extensive first-hand knowledge of piracy" (Konstam 2007: 12). While it's acknowledged that Johnson's work contains some errors and apocryphal accounts (such as the community of Libertalia), "Johnson is widely regarded as a highly reliable source for factual information" on pirates (Rediker 2004: 180) and remains a definitive source historians rely on in constructing their accounts of late 17th- and early 18th-century piracy. As eminent pirate historian David Cordingly put it, this book
} 
century buccaneers. Exquemelin was a surgeon who sailed on a buccaneering vessel and provides a detailed firsthand account of their raids and profit-maximizing strategies. Buccaneers differ from 'pure' pirates in that they frequently plundered ships with government sanction. However, many other times they plundered without official permission, as full-blown pirates. These proto-pirates, many of whom turned to pure piracy when governments stopped issuing licences for plunder, influenced and anticipated the practices of pure pirates in the "Golden Age" (1716-1726), which this paper focuses on.

Additionally, I draw extensively on court records from pirate trials, 18th-century newspaper accounts of pirate activity, which as I discuss below played an important role in publicizing pirates' reputation, and the Calendar of State Papers, Colonial Series, America and West Indies (CSPC), which contains correspondence from colonial governors and others relating to piracy. I also rely on papers from London's Public Records Office (PRO), which is a veritable treasure trove of primary source historical materials relating to pirates. ${ }^{5}$ Finally, a few pirate captives, such as William Snelgrave (1734), published longer works describing their captivities. I also draw on these accounts, which provide important firsthand records describing infamous pirate practices. ${ }^{6}$

\section{Skull \& Bones: The Economics of the Jolly Roger}

\subsection{Surrender or Die}

To maximize profits pirates had to minimize costs. Chief among these were the costs associated with battling potential prizes. Pirate ships often outmanned and outgunned their quarries by a factor of three or more. But merchant ships weren't defenseless. Most carried some armaments. And even though winning a battle with a pirate crew was unlikely, damaging the pirates and their ship wasn't. Battle-sustained deaths or injuries were of course costly to pirates: dead or injured men made less able sea dogs than living or uninjured ones.

Battle-sustained damage to pirates' ship was costly too. First, it reduced pirates' effectiveness in chasing and defeating later prey. A pirate ship with a hole in it, for example, was slower and less agile than an undamaged one. Second, since pirates stole their ships, a damaged ship

\footnotetext{
"is the prime source for the lives of many pirates of what is often called the Golden Age of Piracy" (2006: xx).

${ }^{5}$ With the exception of those from the Boston New-Letter, many of which I collected independently, unless otherwise noted all newspaper accounts are reprinted in Baer (2007: Vol. 1).

${ }^{6}$ Additionally, this paper relies on and is greatly indebted to a voluminous modern literature covering all aspects of piracy, including those considered here, written by contemporary historians. Some of the best discussions belong to Rediker (1987, 2004), Cordingly (2006), Gosse (1946), Rankin (1969), Pringle (1953), Konstam (2002), and Rogozinski $(2000)$.
} 
reduced pirates' ability to take undamaged ones as replacements. ${ }^{7}$ Because of this, a damaged vessel required repair. However, more time repairing meant less time plundering and a higher probability of capture. Walter Moore, for example, captain of the Eagle, captured George Lowther's pirate crew while it careened on an island off Venezuela. Finally, pirates found battle costly because it could damage the prize. Pirates valued stolen ships since they sometimes "traded up" when they took a better vessel and a damaged ship was less useful to them than an undamaged one. In the extreme, if pirates inadvertently sunk their target, the entire prize would be lost. Thus violent conflict not only contributed to the cost side of pirating expeditions, but could diminish the revenue side as well.

To minimize these costs, pirates sought to overwhelm victims without violence. "[T]heir whole policy was directed towards taking prizes without having to fight for them" (Pringle 1953: 113). Pirates' strategy was simple. First, promise to slaughter merchantmen that resisted them. As one pirate described this promise to a prisoner, "No Quarter should be given to any Captain that offered to defend his Ship"' (Snelgrave 1734: 206). Second, promise to show mercy to merchantmen that peacefully surrendered. By manipulating targets' incentive to yield to them-dramatically raising targets' cost of resistance while simultaneously raising the benefit of surrender - pirates hoped to capture merchantmen without violence

Crucial to this strategy's effectiveness was pirates' ability to credibly commit to their "surrenderor-die" policy. However, for reasons similar to those that made conflict costly for pirates in the first place, following through on their promise to slaughter resistant merchantmen after subduing them was also costly. Pirates didn't reap any immediate benefits by punishing a merchantman after they overcame it and the prize was under their control. This was as true for vessels pirates had to fight for as it was for those they didn't. In contrast, pirates could incur immediate costs by fulfilling their deadly promise. Merchant sailors anticipating their execution might, for instance, hazard a last, desperate hand-to-hand resistance that could maim, or even kill, one or two members of the pirate crew. Thus, in the short run at least, massacring resistant merchantmen yielded pirates net costs rather than benefits.

This created a commitment problem for pirates' promise to punish resistors reminiscent of incumbent firms' commitment problem in promising to punish entrants in the chain store paradox. Pirates overcame this problem by invoking the same solution the Gang of Four identified for incum-

\footnotetext{
${ }^{7}$ In the early 18 th century pirates didn't fence ships they stole. Pirates valued vessels as means of piracy and on rare occasions for ransom. But pirates don't seem to have participated in anything like market for plundered ships.
} 
bent firms in this situation: reputation. Following Milgrom and Roberts (1982: 304), the theory of reputation building predicts that if pirate victims were (1) multiple; (2) uncertain about their attacker's motives (and thus payoff of punishing resistance); and (3) could observe pirates' past actions, pirates could maximize their long-run payoff by building a reputation for mercilessly killing resistors that deterred future merchantmen from resisting. The larger long-run payoff of building such a reputation would enable them to credibly commit to their surrender-or-die policy.

And this is what pirates did. As condition (2) suggests, for this deterrence strategy to work merchantmen needed to assign a positive probability to the possibility pirates enjoyed punishing resistors - that is, that punishing resistors yielded pirates immediate net benefits instead of costs. As I discuss further in Section 4, in this way pirate victims' beliefs about sea dogs' motives and disposition were crucial to pirates' ability to develop a reputation that prevented merchantmen's resistance before and after pirates boarded them. By undertaking actions merchantmen interpreted as evidence that pirates enjoyed punishing resistors (and thus that pirates' payoff of punishing resistance was higher than their payoff of not doing so), pirates could create the reputation they needed to make their deterrence strategy effective. As Kreps and Wilson describe the situation for incumbent firms, "the actions taken by the monopolist need not make predation actually ex post optimal - what they must do is . . . increase the probability assessed by the entrants that it is $e x$ post optimal. If deterrence is the objective, the appearance and not the reality of ex post optimal predation may be what is important" (1982: 277).

There was a clear action pirates could take to create the appearance annihilation was ex post optimal if merchantmen resisted: annihilate merchantmen that resisted. Pirate captain Edward Low, for example, "had [a victim's] Ears cut off close to his Head, for only proposing to resist . . . [his] black Flag" (Johnson 1726-1728: 335). In another case Low's crew came upon a ship, "and because at first they shewed Inclinations to defend themselves and what they had, the Pyrates cut and mangled them in a barbarous Manner" (Johnson 1726-1728: 324). Similarly, Bartholomew Roberts' pirate crew assaulted a Dutch interloper, which, after "mentaining an obstinate defence for four hours . . . killed a great many of the pirates." Ultimately, however, the interloper "being overpower'd was forced to submit and what men the pirates found alive on board they put to death after several cruel methods" (News from Barbadoes, Antigua and Jamaica - Sent April 25, 1721 from Governor Bennett to the Council of Trade and Plantations, CSPC, February 18, 1721: Item 463 iii, Vol. 32 (1720-1721), pp. 294-296).

The same costliness of following through on pirates' deadly promise to resistant merchantmen 
made pirates' commitment to follow through on their peaceful promise to compliant merchantmen credible. Since, as noted above, murdering a compliant merchant crew was costly and, further, provided no offsetting reputational benefit as murdering a resistant crew did, pirates had no incentive to slaughter compliant merchant crews. Indeed, pirates had a strong incentive not to kill surrendering victims. Rather than reducing pirates' cost of taking future prizes, slaughtering compliant merchant crews would increase pirates' cost of taking future prizes.

The reason for this is straightforward. If merchantmen expected pirates to murder them whether they resisted or not, they would have an incentive to always resist pirate attacks, undermining pirates' purpose. In this case resisting would be no costlier than surrendering. And, since there was at least a chance resistance might succeed, merchantmen would always want to do so. The theory of reputation building therefore predicts pirates would fulfill their promise of mercy if merchantmen surrendered.

Consistent with this prediction, pirates reserved annihilation for resistant crews, showing mercy to those that peacefully surrendered. As one pirate pointed out to his captive, for example, they "observe strictly that Maxim established amongst them not to permit any ill usage to their Prisoners after Quarter given" (Snelgrave 1734: 219). Indeed, as I discuss below, victims who accepted pirates' offer (peaceful submission and surrender of all booty for your life) not only lived to tell the tale of pirate mercy, but in some cases lived to tell the tale of pirate generosity. This explains why the British government had to resort to legal sanctions to compel armed merchantmen to resist their pirate attackers, which it did, though unsuccessfully, in a 1721 statute (8 Geo. I, c.24). Because merchantmen received mercy when they surrendered to pirates, they didn't hesitate to do just that.

Pirates' surrender-or-die policy and their associated reputation for adhering to its terms spread to prospective prizes through word of mouth and newspaper reporting. An article published in the Boston News-Letter highlights both how pirates' reputation for adhering to this policy was well known to sailors and also how newspaper reporting unwittingly contributed to and helped spread pirates' reputation by reiterating for sailors the consequences of resisting pirate assault. As the article reported, merchantmen "that have made Resistance have been most barbarously butchered, without any Quarter given them, which so intimidates our Sailors that they refuse to fight when the Pirates attack them" (Boston News-Letter June 16-June 23, 1718). Newspaper reporting also publicized pirates' commitment to mercifully treating merchantmen that peacefully surrendered. One paper, for instance, published pirate captain Ned Low's company's articles, which enshrined 
pirates' peaceful promise in writing. This was "Good Quarters to be given when Craved," the newspaper pointed out (Boston News-Letter August 1-August 8, 1723). Newspaper reporting on the consequences of acquiescing to or resisting pirate attack is just one way the 18th-century media unwittingly facilitated pirates' profit-enhancing strategies. As I discuss in Section 4, media coverage was also indispensable to helping pirates cultivate and cash in on a lucrative reputation as "hair triggers."

\subsection{Bringing in the Black Flag}

Pirates' desire to minimize the cost of overtaking prey explains their policy toward merchantmen. But, by itself anyway, it doesn't explain why pirates flew the Jolly Roger. To understand why pirates used this ominous flag and its connection to pirates' policy discussed above, we must turn to signaling theory. This theory, recall, predicts the use of costly signals when there are multiple "types" of agents whose identities are important in shaping some third party's decision about how to act toward them but aren't directly observable.

Pirates, it turns out, found themselves in precisely this situation. They were one of two major types of belligerent mariners merchantmen traveling in and around the Caribbean might confront in the early 18th century. The Jolly Roger was the costly signal pirates used to distinguish themselves from the other type- the Spanish coast guard.

"Guarda Costa" were government-commissioned vessels charged with protecting Spanish territories from illicit foreign traders called "interlopers." Officially, the coast guard was restricted to taking interlopers near the coasts it protected. But in practice these ships often cruised the waters far from shore in search of other countries' merchant vessels carrying any goods they could use to justify seizing in alleged violation of the law that restricted trade with Spain's possessions in the Caribbean. ${ }^{8}$ From the end of the War of Spanish Succession in 1713 through the end of the Golden Age of Piracy in the late 1720s, British colonial officials in the West Indies and North America complained of the overzealous coast guard, which was capturing and condemning British trading vessels against the peace created in the Treaty of Utrecht (see, for instance, Boston Gazette, July 6-July 13, 1724; Governor Sir N. Lawes to the Council of Trade and Plantations, CSPC, May 18,

\footnotetext{
${ }^{8}$ I focus on the Spanish coast guard here because these ships were the most enthusiastic enforcers of their county's trade monopoly in the Caribbean. However, French coast guard vessels also preyed on foreign merchant ships sailing in the West Indies. As merchant ship captain Brathwaite complained to the governor of Bermuda, for instance, hostile vessels "calling themselves guards of the coast . . . pretend to a commission from the General of Martinique for that end. But under that pretence take all English vessels they can overcome whether near the coast or at sea" (Captain Brathwaite to Governor Hart, CSPC, February 14, 1723: Item 496 i, Vol. 33 (1722-1723), p. 240).
} 
1722: Item 142, Vol. 33 (1722-1723), pp. 69-70; Deposition of John Kenney, CSPC, December 10, 1716: Item 425 i, Vol. 29 (1716-1717), pp. 230-231; Governor Sir N. Lawes to the Council of Trade and Plantations, CSPC, January 31, 1719: Item 34, Vol. 31 (1719-1720), pp. 12-21; Lt. Governor Spotswood to the Council of Trade and Plantations, CSPC, May 31, 1721: Item 513, Vol. 32 (1720-1721), pp. 326-329; Deposition of Richard Thompson, CSPC, April 22, 1725: Item 574 v, Vol. 34 (1724-1725), pp. 359-360; Lt. Governor Pulleine to the Council of Trade and Plantations, CSPC, April 22, 1714: Item 651, Vol. 27 (1712-1714), pp. 332-334; Governor Hart to the Council of Trade and Plantations, CSPC, April 9, 1723: Item 496, Vol. 33 (1722-1723), pp. 238-241; Lt. Governor Spotswood to the Council of Trade and Plantations, CSPC, May 31, 1717: Item 595, Vol. 29 (1716-1717), pp. 316-321).

In 1726, for example, the merchants of London petitioned government officials imploring them to address the problem. "It has been a general practice, with the subjects of his Catholic Majesty in the West Indies," they wrote, "for several years past to fit out vessels in a warlike manner, on pretence of gaurding their coasts from unlawful traders: but, in reality under colour of such commissions have committed many depradations, and other acts of hostility, on your Majesty's subjects, on the high seas, and even on the coasts of Jamaica . . . It is notorious those guarda de la costa's, as they are called, never met with an English vessel, and could overcome, which they did not take, destroy or plunder" (Petition of the Merchants of London, CSPC, May 20, 1726: Item 152, Vol. 35 (1726-1727), pp. 74-75; see, also, Merchants trading to Jamaica to the Council of Trade and Plantations, CSPC, May 31, 1724: Item 195, Vol. 34 (1724-1725), pp. 104-105).

British merchant sailors and colonial officers criticized the Spanish coast guard for inhumanely treating prisoners they took under questionable commission. Nevertheless, as government-sanctioned cruisers, at least in principle, authorities limited the viciousness coast guard vessels could show toward merchant crews they assaulted. ${ }^{9}$ Unlike pirates whose outlaw status meant they weren't even theoretically constrained in how they could treat merchantmen they encountered, coast guards weren't permitted to wantonly slaughter merchantmen that resisted them once these crews cried out for quarter, for instance. This important difference between pirates and legitimate belligerents points to the problem pirates faced. If a merchantman believed it was under coast guard, as opposed to pirate, attack, it would have a greater incentive to resist its attacker, undermining pirates'

\footnotetext{
${ }^{9}$ English privateers, for example, were instructed: "That no Person or Persons taken or surprised by you in any Ship or Vessel as aforesaid, though known to be of the Enemies side, be in cold Blood killed, maimed, or by Torture or Cruelty in humanly treated contrary to the Common Usage or Just Permission of War" (The Arraignment, Tryal, and Condemnation, of Capt. John Quelch 1704: 21).
} 
ability to prevent costly conflict through their surrender-or-die policy.

This helps explain captain William Wyer's crew's response when Wyer asked his men if they would "defend their ship" from an unknown approaching belligerent. "[T]hey answered, if they were Spaniards they would stand by him as long as they had Life, but if they were Pirates they would not Fight." When it turned out Blackbeard's pirate crew was the belligerent bearing down on them, consistent with the effectiveness of pirates' reputation for adhering to their surrender-ordie policy discussed above, "Wyers Men all declared they would not Fight and quitted the Ship believing they would be Murthered by the Sloops Company" (Boston News-Letter June 9-June 16, 1718).

Crucially, then, to reap such rewards from their reputation, pirates needed a signal that distinguished them from coast guard attackers and communicated their piratical identity to prospective prizes. That signal was the Jolly Roger. Ironically, rather than an emblem of blood-thirsty pirates, the Jolly Roger reflected pirates' strong desire to avoid violent conflict with prey.

The first recorded account of the Jolly Roger is on the pirate Emanuel Wynne's ship in 1700. A witness described it as "A Sable Flag with a White Death's Head and Crossed Bones in the Fly" (quoted in Grey 1971: 17). Although, as I discuss below, it was but one of several similarly themed, though different, pirate flags, the skull-and-bones motif has received the most attention. Pirates coordinated on this theme for their flags through their common background in legitimate life. Nearly all sea scoundrels were ex-merchant or Royal Navy sailors. Even more so than today, in the early 18th century seafaring was a dangerous occupation. Many sailors died from accident, disease, or violence. A common way of denoting sailors' deaths in ship records was to draw a small skull and bones next to their names in the ship's log. In a macabre twist on this shared experience, as pirates, former merchant and navy sailors adopted this well-known symbol of death to signal their identity (Rediker 1987: 279).

Pirates' reliance on their shared experience as legitimate seamen as a focal point in coordinating the imagery that graced their flags is similar to Mafiosi's reliance on Hollywood movies about Mafia life to settle on the signals they use to establish their identity (see, Gambetta 1994; Varese 2006b). ${ }^{10}$ In both cases behaviors and symbols that were common knowledge to each outlaw group's respective members - in the one case because of a common occupational history, and in the other because of popular and readily provided Hollywood stereotypes - assisted organized criminals in coordinating

\footnotetext{
${ }^{10}$ Varese's (2006b) fascinating paper discusses the Mafia's participation in the creation of its Hollywood image-a manipulation of popular perception similar in many respects to pirates' manipulation of their image through 18 thcentury newspaper reporting, discussed in this paper.
} 
on useful signals of their respective identities. ${ }^{11}$

As I discuss below, the familiar pirate logo, a "large black Flag, with a Death's Head and Bones a-cross," was but a starting point for many crews, which modified their flags using this basic design as a template (Trials of Eight Persons 1718: 24; see also, Boston News-Letter June 9-June 16, 1718; Tryals of Major Stede Bonnet 1719: v, 16). Although the specific images on Jolly Rogers varied, the purpose was the same in each case. As one witness described it in the pages of the White-hall Evening Post, the "black Flag with a Death's Head in it . . . is their Signal to intimate, that they will neither give nor take Quarter" (White-hall Evening Post October 18-October 21, 1718). By communicating "pirate" to merchantmen, the Jolly Roger helped merchantmen understand they were under attack by piratical belligerents who could and would devastate them if they resisted, as opposed to "legitimate" belligerents who were likely to be more restrained in how they responded to resistance.

There was one problem, however. Recall that for a signal to create a separating equilibrium, which here refers to merchantmen's ability to perfectly infer whether their attacker is the piratical or legitimate variety based on whether it flies the Jolly Roger or not, the Jolly Roger must be cheap for pirates, but prohibitively expensive for coast guards, to use.

The Jolly Roger was inexpensive for pirates. Pirates were already outlaws. If they were caught, their punishment was the same whether they flew the black flag or not-hanging. In contrast, because legitimate belligerents weren't outlaws, but flying the Jolly Roger would make them so, the Jolly Roger was more expensive for them to use. While some coast guards operated in a legal grey area, absent what one group of British colonials called "due proof of the[ir] illegal captures and other depredations" - i.e., clear evidence they were engaged in piracy — coast guards enjoyed legal protection as legitimate, government-commissioned ships (Petition of the Merchants of London and Others Trading to and Interested in the British Colonies in America, CSPC, May 20, 1726: Item 152, Vol. 35 (1726-1727), pp. 74 - 75). This meant they couldn't be hunted and hanged as pirates.

For instance, in 1722 Jamaican governor Sir Nicholas Lawes wrote to the Council of Trade and Plantations to describe the trial and hanging of 50 Spanish coast guard sailors. In his letter, Lawes

\footnotetext{
${ }^{11}$ Another interesting similarity between pirate and Mafia signaling practices relates to their names. As Gambetta (1994) points out, with varying degrees of success, Mafiosi adopt colorful nicknames for themselves and even give attention to the way they name their criminal outfits. Pirates displayed similar behaviors. Several pirate captains had special nicknames, for instance, Blackbeard being the most famous, but also "Calico" Jack Rackam, "Black Bart" Roberts, and so on. Similarly, pirates named their vessels with particular, and memorable themes in mind. The names of nearly 20 percent of a sample of 44 early 18th-century pirate ships, for instance, refer to revenge (Rediker 1987: 269). Unlike other pirate and Mafia signals, these naming signals are cheap and easily appropriated by fakers. Still, it seems reasonable to conclude that they must have provided some, at least temporary, benefit or else these organized criminals wouldn't have resorted to them.
} 
is clear that since coast guards have government commissions, unless strong evidence of piracy could be adduced, their commissions protect them as legal enterprises and they couldn't be punished. Unfortunately for the coast guard sailors Lawes "brought to a trial, the Comander [only] pretended he had a commission . . . to be a guard de la coast but it having been plainly proved that he had taken two English vessels who were going on their lawfull occasions and noways near to or within the sight of any part of Hispaniola, the Judges found them all guilty of piracy except seven" (Governor Sir N. Lawes to the Council of Trade and Plantations, CSPC, May 18, 1722: Item 142, Vol. 33 (1722-1723), pp. $69-70)$.

Of course, one of the clearest ways for a coast guard to "plainly prove" it was pirating was to fly a pirate flag. The Jolly Roger was a well-known emblem of piracy. Carrying it was thus prima facie evidence one had stepped beyond the bounds of legitimate cruising into the realm of sea banditry. As the court declared at the trial of Bartholomew Roberts' crew, the accused had acted "under a Black Flag, flagrantly by that, denoting your selves common Robbers, Opposers and Violators of all Laws, Human and Divine" (A Full and Exact Account, of the Tryal of all the Pyrates 1723: 5).

Unlike coast guards that operated near their government's coasts and used national flags, coast guards that used pirate flags therefore opened themselves up to being hunted and executed as pirates. For example, Governor Hart of St. Christopher sent a man-of-war "who is now cruizing among the French and Spanish Islands of these practices, of the Spanish guarda de la costa's; who is resolv'd to bring in all such pirates, where he shall find a black flag." Similarly, "the Dutch Governor of Carassow was fitting out a vessel with 200 men to go in pursute" of a coast guard that "hoists a black flag, and acts like a pirate" (Governor Hart to Mr. Popple, CSPC, November 30, 1726: Item 360, Vol. 35 (1726-1727), pp. 179-180). To retain at least a veneer of legitimacy, coast guards couldn't sail under pirate colors.

Despite the Jolly Roger's higher cost for legitimate belligerents, it proved unable to secure the separating equilibrium pirates sought. Instead, it generated a semi-separating equilibrium in which pirates used the pirate flag but some coast guards did as well. One such coast guard, for example, "when he finds any vessel he can overpower, hoists a black flag, and acts like a pirate. But if he meets any ship of war, or others that are too strong for him, he then produces a Commission from the Governor of Porto Rico, as a Guarda de la Costa" (Governor Hart to Mr. Popple, CSPC, November 30, 1726: Item 360, Vol. 35 (1726-1727), pp. 179-180; see also, Petition of the Merchants of London, CSPC, May 20, 1726: Item 152, Vol. 35 (1726-1727), pp. 74-75).

The reason for this is straightforward. In the same way that, as Gambetta (1994) and Smith 
and Varese (2001) point out, the success of Mafia signals encourages fakers to appropriate them, partly undermining these signals' effectiveness, so too did the pirate flag's effectiveness in facilitating easier merchantman surrender encourage some coast guards to appropriate the Jolly Roger, in effect faking pirate status. The primary factor reducing the cost of the Jolly Roger for some coast guards was a lower probability of capture. British resources were limited. Not all colonial governors had the same ability to send ships after pirate flag-hoisting coast guards. Further, some coast guards, because of better ships or more competent crews, could evade authorities more easily than others. Consequently, not all coast guards were equally susceptible to capture if they flew the Jolly Roger. The lower the chance a coast guard had of facing punishment for cruising under the pirate flag, the closer its cost of using the Jolly Roger was to pirates' cost of doing so. In this way the inconsistencies and imperfection of maritime enforcement, which lowered the cost of flying the Jolly Roger sufficiently for some coast guard vessels to make doing so profitable, contributed to the semi-separating nature of the resulting signaling equilibrium.

Because some coast guards also used the pirate flag, merchant ships couldn't determine their attackers' identity with certainty. Thus, while the Jolly Roger was positively correlated with attackers' "fearsomeness" (i.e., their ability to annihilate resistors), it wasn't perfectly so. As a result, some merchantmen surely resisted pirate attack under the belief their attacker was a poseur. Despite its cleverness, the Jolly Roger couldn't totally eliminate pirates' cost of merchant ship resistance.

But neither was it totally ineffective. If it had been, neither pirates nor coast guards would have bothered to use it. Indeed, by all accounts the Jolly Roger worked extremely well in preventing violent conflict with merchantmen. As one pirate historian notes, "In the great majority of cases merchant ships surrendered without a fight when attacked by pirates" (Cordingly 2006: 121). This suggests the number of pirate poseurs was modest, which explains how the Jolly Roger managed to remain "so effective" for pirates "that they hardly ever needed to kill" (Pringle 1953: 113). Captain Johnson, for example, describes one case in which two French cruisers chased Bart Roberts' crew, mistakenly believing Roberts' vessel to be a foreign merchant ship prohibited by French monopoly from trading in such waters. "[S] upposing him to be one of these prohibited Traders, [the cruisers] chased with all the Sail they could make, to come up with him; but their Hopes, which had brought them very nigh, too late deceived them, for on hoisting of Jolly Roger, (the Name they give their black Flag) their French Hearts failed, and they both surrendered without out any, or at least very little Resistance" (1726-1728: 226). 
Most merchant crews responded to pirate attack in the way Benjamin Edwards' crew did when George Lowther's pirates assaulted them. "[F] earing the Consequence of too obstinate a Resistance against those lawless Fellows," they peacefully submitted to their pirate attackers (Johnson 17261728: 312). Indeed, pirate captain Ned Low simultaneously attacked several vessels and managed to take them all without spending so much as a bullet. "He threaten'd all with present Death who resisted, which stuck such a Terror to them, that they yielded themselves up a Prey to the Villains, without firing a Gun" (Johnson 1726-1728: 323). The Jolly Roger's success explains the surprising confidence one tiny pirate crew exhibited. Though they had only five crewmembers among them, they "sail'd away down the Coast, making them a black Flag, which they merrily said, would be as good as fifty Men more, i.e. would carry as much Terror" (Johnson 1726-1728: 371).

\subsection{Trademark Yer Terror: Overcoming Pirate Free Riding, Part I}

Coast guards weren't the only mariners who threatened to undermine the Jolly Roger's effectiveness: certain members of the pirate community threatened to as well. Not all pirate crews were equally strong or effective. Some had more crewmembers; others had more firepower or better ships. Further, some pirate captains were more capable leaders than others. For example, the "gentleman pirate," Major Stede Bonnet, had all he could do to figure out how to pirate at all. Bonnet was so clueless he actually purchased his first pirate ship (whereas proper pirates stole theirs) and paid his crewmembers fixed wages (whereas proper pirates were compensated in shares of booty).

A weaker, inept pirate crew could ruin the Jolly Roger's effectiveness for stronger, more able ones because if a merchantman happened to resist despite seeing the pirate flag, the weak crew might be forced to flee, or worse yet, be defeated. If this happened enough, the Jolly Roger's toothy grin would cease to operate as a symbol to be feared and submitted to. Even stronger pirate crews would then confront resistance more often, resulting in the costs they devised the Jolly Roger to avoid.

Pirates' solution to this dilemma was simple: they customized their flags. The classic skull-andbones on black pattern was but one of a large variety of crew-specific Jolly Rogers pirates used. Other Jolly Rogers featured hourglasses, full skeletons, flexing arms, swords, bleeding hearts, and related symbols of strength, death, and destruction. A pirate crew discussed by Captain Johnson, for example, "let fly her Jack, Ensign and Pendant, in which was the Figure of a Man, with a Sword in his Hand, and an Hour-Glass before him, with a Death's Head and Bones." Another "had the Figure of a Skeleton in it, and a Man pourtray'd with a flaming Sword in his Hand, intimating 
a Defiance of Death itself" (Johnson 1726-1728: 68; 245). Pirate captain Francis Spriggs' crew favored a "Jolly Roger, (for so they call their black Ensign)" that had "in the middle of . . . [it] a large white Skeleton, with a dart in one hand, striking a bleeding Heart, and in the other an Hour Glass" (British Journal August 22, 1724; see also, Boston Gazette March 21-March 28, 1726; New England Courant July 22, 1723).

Some pirate crews took customizing their flags even further. Bart Roberts, for example, tailored his ship's flag to send a pointed message to the governors of Barbados and Martinique who dared to send warships to bring the notorious pirate captain to justice. According to Johnson, "Roberts was so enraged at the Attempts that had been made for taking him, by the Governors of Barbadoes and Martinico, that he ordered a new Jack to be made, which they ever after hoisted" (1726-1728: 221). Thereafter this crew had "a black Silk Flag flying at their Mizen-Peek, and a Jack and Pendant of the same: The Flag had a Death's Head on it, with an Hour-Glass in one Hand, and cross Bones in the other, a Dart by it, and underneath a Heart dropping three Drops of Blood-The Jack had a Man pourtray'd in it, with a flaming Sword in his Hand, and standing on two Skulls, subscribed A.B.H. and A.M.H. i.e. a Barbadian's and a Martincan's Head" (Johnson 1726-1728: 234; see also, 352).

Because they tended to share basic color schemes and themes, pirate flags were similar enough to signal "pirate," but different enough to communicate the identity of the particular crew that sailed under it. This permitted stronger or more effective pirate crews to internalize the benefits of their strength and aptitude, preventing weaker and less able crews from free riding on their strength and undermining the Jolly Roger's effectiveness. Eighteenth-century newspapers, which published pirate victims' accounts, sometimes described the particular flag the crew they encountered sailed under, as well as its manpower and fire power, and even the disposition of the captain or other crewmembers (see, for instance, Boston News-Letter, May 28-June 4, 1724; New England Courant July 22, 1723; Boston Gazette March 21-March 28, 1726; British Journal August 22, 1724; Baer 2007 I: 282). This helped merchantmen who confronted a particular Jolly Roger to have an idea about the crew that sailed under it.

Weaker crews don't seem to have attempted appropriating the particular flags of stronger ones. There's a good reason for this. Even at its peak, in any year during piracy's Golden Age (17161726) the pirate population was relatively small - about 2,000 men. Further, according to Marcus Rediker, more than 70 percent of these pirates can be genealogically connected to only three pirate captains (Rediker 1987: 267). Many of these rogues lived on and operated from a small number 
of land bases. The most important of these was the one Woodes Rogers went to squelch at New Providence in the Bahamas, which most pirates called home in the early 18th century. The pirate population was therefore modestly sized and close knit. A weak crew that tried to steal a stronger crew's flag would consequently have faced a strong likelihood of being discovered and punished by the stronger crew. Besides, at least in some cases there was a better, much safer, way of enjoying the benefit of a stronger, more effective pirate crew. If it could convince a stronger crew to allow it, a weaker crew might sail in consort with the stronger one. This is ultimately what Major Stede Bonnet's pirate crew did, for example, joining Blackbeard's crew briefly as it plied North America's Atlantic coast.

\section{Walk the Plank: The Economics of Pirate Torture}

\section{1 "Hair Triggers"}

Unfortunately for pirates, even after they boarded a prize that peacefully surrendered to the Jolly Roger, their job was far from finished. After taking control of their prey, pirates needed to locate the loot. The problem they faced in doing so was simple enough: victims weren't keen to give it up.

Some captured crewmembers hid valuables, such as the "Rings and Buckles" the cook on one of Roberts' prizes stashed away (A Full and Exact Account, of the Tryal of all the Pyrates 1723: 14). Other passengers destroyed booty to prevent pirates from taking it. A merchant captain who Edward Low attacked, for example, "hung eleven thousand moydores of gold in a bag out of the cabbin window, and as soon as he was taken by the said Lowe, cutt the rope and lett them drop into the sea" (Governor Hart to the Council of Trade and Plantations, CSPC, March 25, 1724: Item 102, Vol. 34 (1724-1725), pp. 71-73). Uncooperative captives such as this, who successfully hid or destroyed booty, reduced pirates' haul.

To prevent this, pirates sought to develop a reputation as "hair triggers," men who would unleash unspeakable savagery on those who crossed them and could be pushed over the brink of sanity and restraint by even the slightest transgression. To successfully create this reputation pirates needed to achieve three closely related goals. First, they needed to establish their image as men who could easily be pushed over the edge. Second, they needed to establish a reputation for going berserk when in fact this occurred. Finally, they needed to advertise their status as "hair triggers." 
Pirates achieved their first goal by behaving like men on the brink of sanity in front of those they overtook. One way they did this was by fostering a "devil-may-care" image among the legitimate persons they interacted with. For instance, pirates loudly proclaimed to those they overwhelmed that they feared neither death nor the law. As the British Journal reported, for instance, the members of one pirate crew declared to their captives that "They have no Thoughts of ever being taken, but swear, with the most dire Imprecations, that if ever they should find themselves overpower'd, they would immediately blow their Ship up, rather than do Jolly Roger the Disgrace to be struck, or suffer themselves, to be hang'd like Dogs" (British Journal August 22, 1724). Or, as the Boston News-Letter reported, according to another pirate prisoner, his captors went about "often saying they would not go to Hope Point in the River of Thames to be hung up in Gibbets a Sundrying . . . for if it should chance they should be Attacked by any Superiour Power or Force, which they could not master, they would immediately put fire with one of their Pistols to their Powder, and go all merrily to Hell together!" (Boston News-Letter August 15-August 22, 1720).

Pirates projected this attitude to such an extent that it became something of a sea-dog slogan. As Bartholomew Roberts famously boasted, for example, "a merry Life and a short one, shall be my Motto" (Johnson 1726-1728: 244). The pirate motto was a useful way for pirates to signal they had high discount rates. This was a helpful tactic since, if potential pirate victims (or authorities) viewed pirates as reckless with their own lives, they would be less willing to risk raising pirates' ire. Further, communicating a high discount rate helped make activities that created immediate net costs for pirates, such as massacring resistant merchantmen, discussed above, and torture-forreputation, discussed below, appear to not create such costs, and indeed, even to create immediate net benefits for pirates. This helpfully influenced potential victims' beliefs about pirates' payoffs from engaging in such activities.

This helps shed light on pirate comments, like the remark one of William Snelgrave's pirate captors made, that "as to his part, he hoped he should be sent to Hell one of these days by a Cannon Ball" (Snelgrave 1734: 210). Even the melodramatics of Blackbeard's last stand against Lieutenant Robert Maynard, reported in the Boston News-Letter, helped solidify pirates' image as men on the edge, devilishly hoping for someone to push them over. As the newspaper described it, before engaging Maynard, "Teach called for a Glass of Wine, and swore Damnation to himself if he either took or gave Quarters" (Boston News-Letter February 23-March 2, 1719).

Pirates' further cultivated their image as madmen who could snap and be propelled into a violent rage at the slightest transgression by destroying cargo, throwing parcels of goods overboard, and 
torching ships that weren't up to their piratical standards after overtaking prizes. Consider, for example, how a victim of Bartholomew Roberts' crew described his predators' antics in the Boston News-Letter. According to the victim, Roberts' men proceeded "with madness and rage to tare up the Hatches" and then "enter[ed] the Hould like a Parcel of Furies, where with Axes, Cutlashes, \&c they cut, tore, and broke open Trunks, Boxes, Cases, and Bales, and when any of the Goods came upon Deck which they did not like to carry with them aboard their Ship . . . they threw them over board into the Sea . . There was nothing heard among the Pirates all the while but Cursing, Swearing, Damning, and Blaspheming to the greatest degree imaginable" (Boston News-Letter August 15-August 22, 1720). ${ }^{12}$

Richard Hawkins, who pirate captain Francis Spriggs victimized, described a similar scene of madness about his encounter in the British Journal, noting "every Thing that please them not they threw over board . . . every individual Thing they destroy'd; broke all my Windows, knock'd down the Cabbin . . . and then deliver'd me my Ship in a despicable Condition" (British Journal August $8,1724)$. One pirate victim's account, published in the Boston News-Letter, spoke specifically to the pirates' apparent godlessness and confirmed the popular perception that pirates were "in the Possession of the Devil" and "laughing at the very thunders of God" (An Account of the Behaviour and Last Dying Speeches of the Six Pirates 1704; Coleman 1726: 22). "In ravaging the Vessel," this victim reported, "they met with two or three Bibles, at the sight whereof some started and said, They had nothing to do with them; or with God, nor any thing Above" (Boston News-Letter August 4-August 11, 1718). Those who witnessed such behavior or read about it in newspapers were of course terrified to make any moves that might unleash the pirates' devilish appetites. In short, pirate "madness" had precisely the effect pirates desired.

Pirates achieved their second goal — establishing a reputation for going berserk when they were pushed over the edge by prisoners hiding or destroying booty—by responding to such behavior in the most brutal way they could: with heinous torture. This is the primary reason pirates spent so much time, as one court remarked, "making their Hellish Inventions for unheard of Barbarities" (Tryals of Sixteen Persons for Piracy 1726: 14). ${ }^{13}$

There were two types of pirate torture that affected pirates' reputation. The first, "torture-for-

\footnotetext{
${ }^{12}$ In the same way that 18th-century pirates don't seem to have been able to fence ships, it's likely they had difficulty fencing bulky cargo in some cases as well. In other cases pirates simply didn't have room on their ships for additional cargo. In such cases, burning vessels, throwing cargo overboard, and so on was therefore not as costly a form of cultivating an image as "hair triggers" as it seems.

${ }^{13}$ Although pirates chiefly used torture for profit-serving purposes, as in any population, in the pirate population, too, there were some psychopaths who inflicted harm on others for entertainment.
} 
information," only indirectly contributed to pirates' reputation. As its name suggests, torture-forinformation aimed at extracting information about the location of hidden valuables from prisoners. If pirates suspected a prisoner was holding back valuable loot, they would torture him until he figuratively or literally spilled his guts - whichever came first. As I discuss below, torture-forinformation's helpful effect on pirates' reputation was a beneficial by-product, or side effect, of torture pirates used to extract information from stubborn victims.

An important and distinguishing feature of torture-for-information was its potential immediate profitability. Like slaughtering resistant merchantmen, torturing captives who hid or destroyed valuables could be costly to pirates. A prisoner who realized torture was forthcoming might fight back, injuring, or even killing, his torturer. Perhaps more important, torture took time- especially the slow and painful varieties pirates were partial to described below. Time pirates spent torturing captives was time they couldn't spend searching for their next prize. Despite these costs, however, because torture-for-information enabled pirates to uncover hidden booty-booty potentially valuable enough to more than offset torture's costs - torture-for-information could yield pirates immediate net benefits.

The second kind of pirate torture, "torture-for-reputation," directly contributed to pirates' reputation and, as its name suggests, was administered specifically for this purpose. Unlike torturefor-information, torture-for-reputation always generated immediate net costs. Torturing a prisoner who destroyed loot, for instance, involved the costs of torture discussed above but couldn't create the offsetting benefits torture-for-information could since destroyed booty was unrecoverable. This presented a problem for pirates because to establish a reputation as "hair triggers" they needed to brutally punish all uncooperative captive behaviors relating to loot, including those that destroyed booty. Thus, similar to pirates' policy to massacre merchantmen that resisted the Jolly Roger, pirates confronted a credible commitment problem when it came to torture-for-reputation.

As in the case of the Jolly Roger, here too, the theory of reputation building explains how pirates were able to overcome this problem. Although torture-for-reputation involved more immediate costs than benefits, by contributing to pirates' reputation as "hair triggers" it could dissuade future captives from revenue-eroding behaviors, enhancing pirates' profit. As Kreps and Wilson put it, 'If rivals perceive the slightest chance that an incumbent firm might enjoy 'rapacious responses,' then the incumbent's optimal strategy is to employ such behavior against its rivals . . . For the incumbent, the immediate cost of predation is a worthwhile investment to sustain or enhance its reputation, thereby deterring subsequent challenges" (1982: 254). In this sense torturing a victim 
who, for instance, destroyed booty, was a piratical investment that prevented future captives from doing so. In the same way that, as we saw above, pirates' larger long-run payoff of developing a reputation for slaughtering resistant merchantmen enabled them to credibly commit to this policy despite the immediate net costs doing so created, pirates' larger long-run payoff of developing a reputation for brutalizing prisoners who destroyed booty enabled them to credibly commit to torturing resistant captives even when this created immediate net costs.

Credibly committing not to torture compliant prisoners was more straightforward. As noted above, torture always yielded immediate net costs when prisoners hadn't hidden anything; so it wasn't in pirates' short-run interest to torture compliant captives. Further, wantonly brutalizing prisoners would render torture ineffective for pirates' purpose, undermining the reputation they sought to build rather than contributing to it. If pirates developed a reputation for assured torture, and thus captives expected to be savaged whether they delivered up their valuables or not, captives wouldn't find hiding or destroying loot costly. Thus it wasn't in pirates' long-run interest to torture compliant captives either. The theory of reputation building therefore predicts pirates would show mercy to compliant captives, reserving barbarity for those who hid or destroyed booty.

Pirates' use of torture is consistent with this prediction. Indeed, far from abusing compliant captives, pirates sometimes showed kindness toward them. William Snelgrave's pirate captors, for example, were so pleased with him that by the end of Snelgrave's captivity they offered to gift him a ship loaded with valuable cargo (Snelgrave 1734: 220-228). Merchant ship captain Knott similarly enjoyed pirate "gifts" following his crew's capture in 1720. The pirates "took what they wanted out of the merchantman and gave him money and goods of a very considerable value for the same" (CSPC, May 31, 1720: Item 33 i, vol. 32 (1720-21), pp. 18-19). Rather than brutalizing prisoners indiscriminately, pirates reserved torture for resistant captives as the theory of reputation building predicts. As pirate captain Sam Bellamy put it, "I scorn to do any one a Mischief, when it is not for my Advantage" (Johnson 1726-1728: 587). ${ }^{14}$

As discussed above, pirate "Mischief" was "for [pirates"] Advantage" when it yielded information about the whereabouts of hidden booty (torture-for-information) or contributed to a reputation for punishing uncooperative captives who destroyed booty, preventing costly captive behaviors on

\footnotetext{
${ }^{14}$ Of course, pirates could, and did in some cases, wrongly torture on suspicion of a captive having hidden or destroyed valuables. In one case, for instance, an unfortunate woman who several buccaneers captured "was by some set bare upon a baking stone and roasted, because she did not confess of money which she had only in their conceit" (John Style to 'the Principal Secretary of State, Whitehall,' CSPC, January 4, 1670, Item 138, Vol. 7 (1669-1674), pp. 49-51). But pirates couldn't afford to make this mistake too often lest torture's ability to improve their profit be destroyed.
} 
future ships (torture-for-reputation). For example, in response to the merchant captain discussed above who threw a bag of gold into the ocean to prevent Edward Low's pirate crew from taking it, "Lowe cutt off the said Masters lipps and broyl'd them before his face, and afterwards murder'd the whole crew being thirty two persons" (Governor Hart to the Council of Trade and Plantations, $C S P C$, March 25, 1724: Item 102, Vol. 34 (1724-1725), pp. 71-73). In a newspaper article in the American Weekly Mercury, a witness described how Low's crew treated other resistant prisoners: "They cut and whiped some and others they burnt with Matches between their Fingers to the bone to make them confess where their Money was." Apparently it worked. Low's pirates "took to the value of a Thousand Pistoles from Passengers and others," the article noted (American Weekly Mercury June 13, 1723). ${ }^{15}$

This response to passive prisoner resistance wasn't specific to Low. Pirate captain Charles Vane "bound [one captive's] hands and feet and ty'd (upon his back) down to the bowspritt with matches to his eyes burning and a pistol loaded with the muzzle into his mouth, thereby to oblige him to confess what money was on board" (Deposition of Edward North, CSPC, May 22, 1718: Item 551 ii, Vol. 30 (1717-1718), p. 263). Pirate captain George Lowther also resorted to torture to reveal the location of hidden valuables, "placing lighted matches between the fingers of" his prisoners "to make them discover where the gold was" (Deposition of John Wickstead, CSPC: Item 754 iv, Vol. 33 (1722-1723), p. 365).

The buccaneers had a particular skill for inflicting pain on prisoners who refused to surrender booty. Their practice of "woolding" illustrates this well. Alexander Exquemelin vividly describes this torture, which the buccaneers administered to one recalcitrant prisoner: "they strappado'd him until both his arms were entirely dislocated, then knotted the cord so tight round the forehead that his eyes bulged out, big as eggs. Since he still would not admit where the coffer was, they hung him up by his male parts, while one struck him, another sliced off his nose, yet another an ear, and another scorched him with fire" (1678: 200; see, also, John Style to "the Principal Secretary of State, Whitehall,' CSPC, January 4, 1670: Item 138, Vol. 7 (1669-1674), pp. 49-51).

To another pitiful fellow who refused to divulge the whereabouts of booty, "they tied long cords to his thumbs and his big toes and spreadeagled him to four stakes. Then four of them came and beat on the cords with their sticks, making his body jerk and shudder and stretching his sinews. Still not satisfied, they put a stone weighing at least two hundred-weight on his loins and lit a fire of palm leaves under him, burning his face and setting his hair alight" (Exquemelin 1678: 150).

\footnotetext{
${ }^{15}$ Reprinted in Dow and Edmonds (1996: 206).
} 
The French buccaneer Francois L'Ollonais added a special flair to his torture of several stubborn Spanish prisoners who refused to lead him to their hiding compatriots and money. L'Ollonais "being possessed of a devil's fury, ripped open one of the prisoners with his cutlass, tore the living heart out of his body, gnawed at it, and then hurled it in the face of one of the others" (Exquemelin 1678: 107).

Eighteenth-century pirates developed their own special tortures. Consider, for instance, "the sweat." "The Manner of a Sweat," one pirate prisoner explained in the pages of the British Journal, "is thus: Between the Decks they stick Candles round the Mizen-Mast, and about twenty five Men surround it with Points of Swords, Penknives, Compasses, Forks, \&c. in each of their Hands: Culprit enters the Circle; the Violin plays a merry Jig, and he must run for about ten Minutes, while each Man runs his Instrument into his Posteriors" (British Journal August 8, 1724).

Understanding pirate torture as a rationally-chosen means of recovering hidden booty and developing a reputation to prevent booty destruction provides a rather different interpretation to Captain Johnson's comment that "In the Commonwealth of Pyrates, he who goes the greatest Length of Wickedness, is looked upon with a certain kind of Envy amongst them" (Johnson 17261728: 85; see also, 121). Because the reputation this "wickedness" created contributed to a piratical brand name, heinous pirate torture reduced costly captive behaviors, enhancing pirates' revenue.

Pirates achieved the final goal required to establish their reputation-communicating their status as "hair triggers" to others - by relying on word of mouth and newspaper coverage to publicize this status. For word of mouth to be effective pirates required survivors who could relay the consequences of resisting their demands and spread information about their "hair trigger" disposition to others. Thus, although in some cases it was "good Policy" to sink a captured vessel after relieving her of plunder "to prevent her returning to tell Tales at Home," pirates often released compliant crewmembers to return home where they could communicate what they witnessed (Johnson 17261728: 298). Pirate captain John Phillips established a reputation as a "bloody, merciless ruffian" with the "diabolical disposition of an infernal fiend" this way. Thus when Phillips captured John Fillmore, for instance, Fillmore was "dread to fall into [Phillips'] hands," as he later recorded, "having heard of the cruelties committed by that execrable pirate" (Moseley 1790: 355; 358; 354).

Pirates similarly relied on word of mouth to communicate their civility toward captives who complied with their demands. This helps explain why Philip Ashton's pirate captors, for instance, informed Ashton "that it was one of their Articles Not to Draw Blood, or take away the Life of any Man, after they had given him Quarter" (Barnard 1715: 7). As noted above, to make their point, 
pirates sometimes even made gifts to their compliant victims, a fact they surely hoped their captives would tell others when they were released. And many of their captives did just that. According to Virginia governor Alexander Spotswood, for example, "it is a common practice among the Pirats to make presents to Masters of Ships and Seamen of such Commoditys they have less use of, in lieu of what they take away" (Spotswood May 20, 1720 [1882-1885] II: 340; see also, Johnson 17261728: 597). Since Spotswood was never himself taken by pirates, he could have only arrived at this conclusion after hearing about pirate generosity from sailors pirates had taken.

Perhaps the most effective means of spreading pirates' reputation, however, was through newspaper reporting. In addition to relating information about pirate movements, captures, and facts about crew composition, newspapers also related information from pirate victims and released pirate prisoners. Many of the reputation-building incidents described above, for instance-from pirates' aversion to Bibles to Blackbeard's toast to death-were published in newspapers for the public to consume.

So were the dire consequences of hiding or destroying booty and the sometimes quite amiable consequences of complying with pirate demands. For example, the fact that pirates "barbarously used [merchant captain] Mac Clenan for hiding his Money" was published in the news (Boston News-Letter August 11-August 18, 1718; see also, Boston News-Letter June 24-July 1, 1717). So too was the fact that pirate captain James Feiff "was very Civil" toward a compliant crew "in not abusing any of their men by rude treatment" (Boston News-Letter April 7-April 14, 1718). The Boston News-Letter also duly noted pirate captain Henry Jennings' kindness toward compliant captives. According to merchant captain Stone's experience, published in the paper, Jennings' crew "took . . . from him but 20 Gallons of Rum, for which they gave him some Shoats more than the value, [and] treated him civily" (Boston News-Letter October 29-November 5, 1716). Similarly, the news published pirate captain John Martel's mercy toward cooperative prisoners. Toward one of his victims, the paper reported, Martel "was so civil as to make an Exchange in giving Him his Pyrate Sloop, and otherwise was very kind to him . . . He also gave him a New-London Sloop to come home in" (Boston News-Letter November 5-November 12, 1716).

Significantly, establishing a reputation as "hair triggers" supported pirates' reputation for mercilessness in dealing with resistant merchantmen, discussed in Section 3, and vice versa. Recall that merchantmen's beliefs about pirates' preference for, and thus immediate payoff from, punishing resistors were crucial to pirates' ability to develop a reputation for punishing resistors. By murdering resistant merchantmen and brutalizing prisoners who hid or destroyed booty, pirates bolstered vic- 
tims' beliefs that they would respond savagely to any kind of uncooperative behavior - to use Kreps

and Wilson's (1982: 254) terminology, that they "enjoy[ed] rapacious responses"” to uncooperative behavior. In this way pirates' reputation for punishing merchantmen that refused to surrender to them, and their closely related reputation for punishing prisoners who hid or destroyed booty, mutually reinforced one another.

\subsection{Blackbeard and By-products: Overcoming Pirate Free Riding, Part II}

Similar to the Jolly Roger, the reputational benefits of pirate torture also created a potential free riding problem within the pirate community. If weaker crews could free ride on the reputations built by stronger ones, stronger crews' incentive to torture, and with it, the reputational benefits of such torture, could be destroyed. Two factors militated against this outcome. First, in the same way that, as Section 3 discussed, different pirate crews had their own pirate flags, helping stronger crews internalize the benefit of their strength, different pirate crews - and in particular pirate captains - had their own reputations, which helped them internalize the benefit of activities that contributed them.

Edward Teach, the "notorious pyrate better known by the name of Blackbeard," is the best example of this (Petition of the Council and Assembly of the Settlements in South Carolina to the King, CSPC, February 3, 1720: Item 541, Vol. 31 (1719-1720), pp. 332-343). By creating a horrible and intimidating physical appearance, Teach cut an image so terrifying that it created a bloodcurdling reputation, which over time evolved into something of a Blackbeard brand name. Captain Johnson claims, for example, that "his Beard . . . did not a little contribute towards making his Name so terrible" (1726-1728: 84). Johnson describes the effect Blackbeard achieved with his appearance as follows:

Captain Teach, assumed the Cognomen of Black-beard, from that large Quantity of Hair, which, like a frightful Meteor, covered his whole Face, and frightened America more than any Comet that has appeared there in a long Time.

This Beard was black, which he suffered to grow of an extravagant Length; as to Breadth, it came up to his Eyes; he was accustomed to twist it with Ribbons, in small Tails . . . and then turn them about his Ears: three Brace of Pistols, hanging in Holsters like Bandaliers; and stuck lighted Matches under his Hat, which appearing on each Side of his Face, his Eyes naturally looking fierce and wild, made him altogether such 
a Figure, that Imagination cannot form an Idea of a Fury, from Hell, to look more frightful (1726-1728: 84-85).

"There is no doubt," one Blackbeard historian notes, "that Blackbeard was conscious of the public image he had created" and worked diligently to maintain it (Lee 1974: 22). As discussed above, in newspaper coverage of pirates' activities "Something about their temper might be included to help persons that confront them in the future," which, together with word of mouth, helped spread such captain- or crew-specific reputations (Baer 2007 I: 282). Specific temperaments were therefore attached to specific pirate crews similar to the way specific flags were, which helped particular pirate crews internalize the benefit of their reputational investments. For Blackbeard this certainly appears to have worked. According to historian Angus Konstam who has investigated Blackbeard's life and piratical career extensively, until Blackbeard's final battle with the lieutenant of HMS Pearl, Robert Maynard, who took the bearded icon's life, the world's most notorious and fearsome pirate hadn't so much as killed a single man (2006: 157). His reputation meant he didn't need to.

The second factor that helped ameliorate the destructive effect of reputational free riding is the fact that torture-for-information, which pirates engaged in for extra-reputational purposes, produced reputation-enhancing effects as a side effect, or by product. By torturing captives who withheld information about the location of hidden valuables, pirates not only extracted information that immediately increased their revenue. They also indirectly contributed to their reputation as "hair triggers" who would fly off the handle and respond with violent rage toward any uncooperative prisoner behavior. This supported the reputation pirates sought when they tortured specifically for this purpose, as well as the reputation they sought when they murdered resistant merchantmen. Critically, the direct benefit of torture-for-information - recovered booty - was enjoyed exclusively, and thus fully internalized, by the torturing pirate crew. Thus, even in the face of potential reputational free riding, pirates retained an incentive to torture-for-information, which indirectly contributed to their reputation as "hair triggers" as well.

\section{Concluding Remarks}

My analysis of the economics of infamous pirates practices leads to several conclusions. First, like both legitimate persons and other organized criminals, pirates pursued profit in a world of asymmetric information. Thus, for them as much as anyone else, signaling and reputation played important 
roles in achieving this end. There were two critical aspects to the pirate-prize informational asymmetry. First, merchantmen had difficulty observing the kind of belligerent that was attacking them, which might be pirate but also might not. Second, even after they established an attacker's piratical identity, merchantmen remained uncertain about their attacker's motives/disposition.

The first aspect of this informational asymmetry created a problem for pirates who relied on their outlaw identity to shape targets' incentive to resist them through a surrender-or-die policy. To deal with this problem, pirates developed their infamous flag, the Jolly Roger. The second aspect of the pirate-prize informational asymmetry, in contrast, worked to pirates' advantage. Because merchantmen weren't certain about pirates' motives, pirates could engage in certain behaviors, such as punishing resistors and prisoners who hid or destroyed loot, and present particular images of themselves to shape merchantmen's beliefs about their disposition and inclination to their advantage. Thus pirates worked hard to appear as "hair triggers," manipulating targets' beliefs about their payoff from punishing uncooperative behaviors. In this way pirates successfully exploited targets' uncertainty about their motives to create a reputation that allowed them to increase their haul.

Second, organized criminals in general, and pirates in particular, are public relations-savvy. To spread and strengthen the reputations they build, organized criminals rely on word of mouth and cleverly capitalize on mass media. Pirates, for example, demonstrated an ability to control or "spin" popular perception of themselves by strategically engaging in certain behaviors in front of others and releasing captives who promoted the image pirates sought. By relaying stories about pirates directly to one another through word of mouth and indirectly to each other through newspaper reporting, pirate captives and early 18th-century mass media unwittingly contributed to pirates' reputations as "hair triggers," facilitating pirates' ability to avoid profit-eating costs.

Third, my analysis points to the importance of shared experiences as a mechanism organized criminals use to coordinate on specific signals (such as flags), and symbolism attached to these signals (such as skull and bones), to communicate their identity to prey where it's otherwise difficult to observe. Common cultural, occupational, or other backgrounds within a particular criminal population provide useful focal points for signaling behavior. To the extent that important elements of these backgrounds are widely recognized and understood by the legitimate public criminals prey on - such as Mafiosi stylings, publicized and partially created by Hollywood, or skull and bones, well known as an emblem of death to the maritime community pirates preyed on - this usefulness is further strengthened.

Finally, this paper highlights that organized criminals' behavior, like everyone else's, has a 
rational choice explanation at its foundation. Economists, and even many non-economists, accept this proposition about criminals in general. However, when it comes to pirates the rational choice foundation underlying observed behavior is easily forgotten or ignored. In large part this is because pirate practices are often entertaining, outlandish, and, owing to their popular treatment, even appear mysterious. In reality, however, the colorful features of pirate practice derive from the unique context early 18th-century pirates operated in rather than any difference in, or dearth of, pirate rationality or self-interest. Pirates' infamous practices were rationally-chosen responses to the conditions they confronted in their pursuit of profit and can be understood using insights from basic economic theory. 


\section{References}

[1] A Full and Exact Account, of the Tryal of all the Pyrates, Lately Taken by Captain Ogle . . . 1723. London: J. Roberts. Reprinted in Joel H. Baer, ed., British Piracy in the Golden Age: History and Interpretation, 1660-1730, Vol. 3. London: Pickering and Chatto, 2007.

[2] An Account of the Behaviour and Last Dying Speeches of the Six Pirates . . . 1704. Boston: Printed for Nicholas Boone. Reprinted in Joel H. Baer, ed., British Piracy in the Golden Age: History and Interpretation, 1660-1730, Vol. 4. London: Pickering and Chatto, 2007.

[3] Anderson, Annelise. 1979. The Business of Organized Crime: A Cosa Nostra Family. Stanford: The Hoover Institution.

[4] Arlacchi, Pino. 1986. Mafia Business: The Mafia Ethic and the Spirit of Capitalism. London: Verso.

[5] Baer, Joel H. 2007. British Piracy in the Golden Age: History and Interpretation, 1660-1730, 4 vols. London: Pickering and Chatto.

[6] Barnard, John. 1715. Ashton's Memorial . . . Boston: Printed for Samuel Garrish.

[7] Becker, Gary. 1968. "Crime and Punishment: An Economic Approach." Journal of Political Economy 76: 675-700.

[8] Chang, Juin-Jen, Huei-Chung Lu, and Mingshen Chen. 2005. "Organized Crime or Individual Crime? Endogenous Size of a Criminal Organization and the Optimal Law Enforcement." Economic Inquiry 43: 661-75.

[9] Cordingly, David. 2006. Under the Black Flag. New York: Random House.

[10] Dick, Andrew R. 1995. "When Does Organized Crime Pay? A Transaction Cost Analysis." International Review of Law and Economics 15: 25-45.

[11] Dow, George F. and John H. Edmonds. 1996. The Pirates of the New England Coast, 16301730. New York: Dover.

[12] Exquemelin, Alexander O. 1678 [2000]. The Buccaneers of America. Alexis Brown, trans. Mineola: Dover.

[13] Fiorentini, Gianluca, and Sam Peltzman, eds. 1995. The Economics of Organised Crime. Cambridge: Cambridge University Press.

[14] Furbank, Philip N. and W.R. Owens. 1988. The Canonisation of Daniel Defoe. New Haven: Yale University Press.

[15] Gambetta, Diego. 1993. The Sicilian Mafia: The Business of Private Protection. Cambridge: Harvard University Press.

[16] Gambetta, Diego. 1994. "Inscrutable Markets." Rationality and Society 6: 353-368.

[17] Garoupa, Nuno. 2000. "The Economics of Organized Crime and Optimal Law Enforcement." Economic Inquiry 38: 278-88.

[18] Gosse, Philip. 1946. The History of Piracy. New York: Tudor Publishing Company. 
[19] Grey, Charles. 1971. Pirates of the Eastern Seas. London: Kennikat Press.

[20] Jankowski, Martin Sanchez. 1991. Islands in the Streets: Gangs and American Urban Society. Berkeley: University of California Press.

[21] Jennings, William P. 1984. "A Note on the Economics of Organized Crime." Eastern Economic Journal 10: 315-21.

[22] Johnson, Charles. 1726-1728 [1999]. A General History of the Pyrates . . Manuel Schonhorn, ed. New York: Dover.

[23] Konrad, Kai A., and Stergios Skaperdas. 1998. "Extortion." Economica 65: 461-77.

[24] Konstam, Angus. 2007. Scourge of the Seas: Buccaneers, Pirates and Privateers. New York: Osprey.

[25] Konstam, Angus. 2006. Blackbeard: America's Most Notorious Pirate. New Jersey: John Wiley and Sons.

[26] Konstam, Angus. 2002. The History of Pirates. Guilford: The Lyons Press.

[27] Kreps, David M., and Robert Wilson. 1982. "Reputation and Imperfect Information." Journal of Economic Theory 27: 253-279.

[28] Kreps, David M., Paul Milgrom, John Roberts, and Robert Wilson. 1982. "Rational Cooperation in the Finitely Repeated Prisoners' Dilemma." Journal of Economic Theory 27: 245-252.

[29] Lee, Robert E. 1974. Blackbeard the Pirate: A Reappraisal of His Life and Times. WinstonSalem: John F. Blair.

[30] Leeson, Peter T. 2009. "The Calculus of Piratical Consent: The Myth of the Myth of Social Contract." Public Choice, forthcoming.

[31] Leeson, Peter T. 2008a. "The Invisible Hook: The Law and Economics of Pirate Tolerance." New York University Journal of Law and Liberty, forthcoming.

[32] Leeson, Peter T. 2008b. "Social Distance and Self-Enforcing Exchange." Journal of Legal Studies 37: 161-188.

[33] Leeson, Peter T. 2007. "An-arrgh-chy: The Law and Economics of Pirate Organization." Journal of Political Economy 115: 1049-1094.

[34] Levitt, Steven D., and Sudhir Alladi Venkatesh. 2000. "An Economic Analysis of a Drug-Selling Gang's Finances." Quarterly Journal of Economics 115: 755-89.

[35] Milgrom, Paul, and John Roberts. 1982. "Predation, Reputation, and Entry Deterrence." Journal of Economic Theory 27: 280-312.

[36] Moseley, Increase. 1790. A Narration of the Captivity of John Fillmore and His Escape from the Pirates. Bennington, VT: Haswell and Russell. Reprinted in John Richard Stephens, ed., Captured by Pirates: 22 Firsthand Accounts of Murder and Mayhem on the High Seas. Cambria, CA: Fern Canyon, 1996. 
[37] Ordahl Kupperman, Karen, John C. Appleby and Mandy Banton, consultant eds. 2000. Calendar of State Papers, Colonial Series, America and West Indies, 1574-1739, CD-ROM. London: Routledge, published in association with the Public Record Office.

[38] Posner, Eric A. 1998. "Symbols, Signals, and Social Norms in Politics and the Law." Journal of Legal Studies 27: 765-798.

[39] Pringle, Patrick. 1953. Jolly Roger: The Story of the Great Age of Piracy. New York: W.W. Norton.

[40] Rankin, Hugh F. 1969. The Golden Age of Piracy. Williamsburg: Colonial Williamsburg.

[41] Rediker, Marcus. 2004. Villains of All Nations: Atlantic Pirates in the Golden Age. Boston: Beacon.

[42] Rediker, Marcus. 1987. Between the Devil and the Deep Blue Sea: Merchant Seamen, Pirates and the Anglo-American Maritime World, 1700-1750. Cambridge: Cambridge University Press.

[43] Reuter, Peter. 1987. Racketeering in Legitimate Industries: A Study in the Economics of Intimidation. Santa Monica: The Rand Corporation.

[44] Reuter, Peter. 1983. Disorganized Crime: The Economics of the Visible Hand. Cambridge: MIT Press.

[45] Rogozinski, Jan. 2000. Honor Among Thieves: Captain Kidd, Henry Every, and the Pirate Democracy in the Indian Ocean. Mechanicsburg: Stackpole Books.

[46] Selten, Reinhard. 1978. "The Chain Store Paradox." Theory and Decision 9: 127-159.

[47] Skaperdas, Stergios. 2001. "The Political Economy of Organized Crime: Providing Protection when the State does Not." Economics of Governance 2: 173-202.

[48] Skarbek, David B. 2008. "Putting the 'Con' into Constitutions: The Economics of Prison Gangs." Journal of Law, Economics and Organization, forthcoming.

[49] Smith, Alastair, and Federico Varese. 2001. "Payment, Protection, and Punishment: The Role of Information and Reputation in the Mafia." Rationality and Society 13: 349-393.

[50] Snelgrave, William. 1734 [1971]. A New Account of some Parts of Guinea, and the Slave Trade. London: F. Cass.

[51] Spence, Michael. 1973. "Job Market Signaling." Quarterly Journal of Economics 87: 355-374.

[52] Spotswood, Alexander. 1882-1885. The Official Letters of Alexander Spotswood. 2 vols. Richmond: Virginia Historical Society.

[53] The Arraignment, Tryal, and Condemnation, of Capt. John Quelch . . . 1704. London: Ben. Bragg. Reprinted in Joel H. Baer, ed., British Piracy in the Golden Age: History and Interpretation, 1660-1730, Vol. 2. London: Pickering and Chatto, 2007.

[54] The Trials of Eight Persons Indited for Piracy 86 . . . 1718. Boston: John Edwards. Reprinted in Joel H. Baer, ed., British Piracy in the Golden Age: History and Interpretation, 1660-1730, Vol. 2. London: Pickering and Chatto, 2007. 
[55] The Tryals of Major Stede Bonnet . . 1719. London: Benj. Cowse. Reprinted in Joel H. Baer, ed., British Piracy in the Golden Age: History and Interpretation, 1660-1730, Vol. 2. London: Pickering and Chatto, 2007.

[56] The Tryals of Sixteen Persons for Piracy . . . 1726. Boston: Joseph Edwards. Reprinted in Joel H. Baer, ed., British Piracy in the Golden Age: History and Interpretation, 1660-1730, Vol. 3. London: Pickering and Chatto, 2007.

[57] Varese, Federico. 2006a. "How Mafias Migrate: The Case of the 'Ndrangheta' in Northern Italy." Law and Society Review 40: 411-444.

[58] Varese, Federico. 2006b. "The Secret History of Japanese Cinema: The Yakuza Movies'." Global Crime 7: 105-124.

[59] Varese, Federico. 2001. The Russian Mafia: Private Protection in a New Market Economy. New York: Oxford University Press.

[60] Venkatesh, Sudhir Alladi, and Steven D. Levitt. 2000. "Are We a Family or a Business? History and Disjuncture in the Urban American Street Gang." Theory ES Society 29: 427-462.

[61] Woodard, Colin. 2007. The Republic of Pirates. New York: Harcourt.

[62] Zahavi, A. 1975. "Mate Selection - A Selection for a Handicap." Journal of Theoretical Biology 53: $205-214$ 